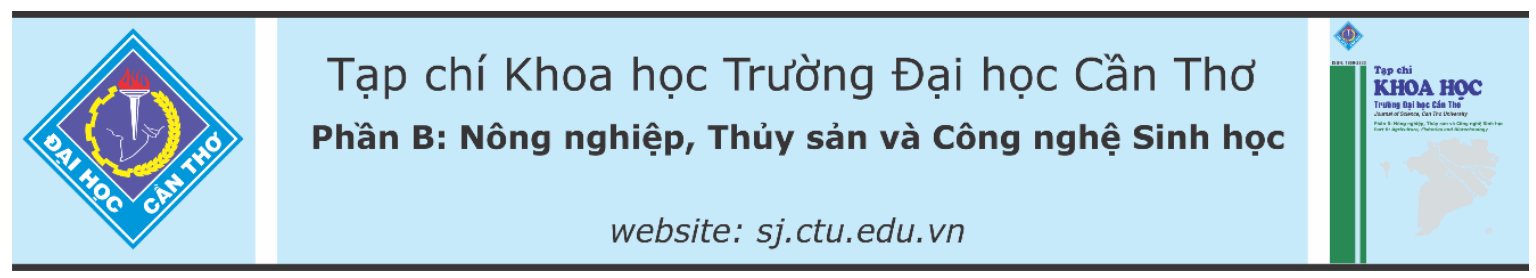

DOI:10.22144/ctu.jvn.2021.012

\title{
KHẢo SÁT CƠ CẤU ĐÀN, NĂNG SUÂT VÀ CHÂT LƯợNG SỬA CỦA ĐÀN BÒ SŨAA TẠI TRANG TRẠI FARM MILK CẦN THƠ
}

Lâm Phước Thành*

Bộ môn Chăn nuôi, Khoa Nông nghiệp, Truờng Đại học Cần Tho

*Người chịu trách nhiệm về bài viết: Lâm Phuoóc Thành (email: phuocthanh@ctu.edu.vn)

\section{Thông tin chung:}

Ngày nhận bài: 22/08/2020

Ngày nhận bài sủa: 28/09/2020

Ngày duyệt đăng: 27/02/2021

\section{Title:}

Investigating herd structure, milk yield and milk

composition of dairy cows at Can Tho Farm Milk

\section{Tù khóa:}

Bò sũa, co cấu đàn, Farm Milk, năng suất sũa, thành phần sũa

\section{Keywords:}

Dairy cattle, Farm Milk, herd structure, milk composition, milk yield

\section{ABSTRACT}

A study was conducted to evaluate herd structure, milk yield and milk composition of dairy cows at Can Tho Farm Milk. This farm has total 408 dairy cattle, but the study just focused on lactating cows. The cows at Farm Milk were divided into two groups including $A(\geq 15 \mathrm{~kg}$ milk/day) and $B(15$ $\mathrm{kg}$ milk/day). Results showed that ratio of cows on lactation was only $22.8 \%$, whereas this number of heifers was $28.2 \%$. CP consumption of group B was sufficient, but lack of CP consumption was found in group A (-0,33 kg/day). Average milk yield at farm was $14.15 \mathrm{~kg} /$ day comprising of $16.54 \mathrm{~kg} /$ day in group A and $11.13 \mathrm{~kg} /$ day in group $B$. Milk yield of lactating cows reached a peak at 2 months postpartum (20.40 kg/day) and decreased to 10.25 at 9 months after parturition. Group B has high content of milk fat, protein and total solid (4.02, 3.51 and 12.66) compared to those of group A (3.39, 3.09 and 11.70). In conclusion, the rate of cows on lactation at Farm Milk was low, but this can be solved in near future due to high numbers of heifers. The greater milk yield was observed at Farm Milk in comparison to other farms in the Mekong Delta. Milk compositions were quite high in group B while these were a little low in group A.

\section{TÓM TÁ́T}

Đề tài được thực hiện nhằm đánh giá hiện trạng co cấu đàn, năng suất và thành phần sũa của đàn bò sữa tại trại bò sũa Farm Milk Cần Tho. Tổng đàn của trại hiện có 408 con, khảo sát tập trung vào nhóm bò đang cho sũa. Bò cho sũa tại trại được chia thành hai nhóm là: $A(\geq 15 \mathrm{~kg}$ sũa/ngày) và $B(<15$ $\mathrm{kg}$ sũa/ngày). Kết quả cho thấy bò đang cho sũa chiếm tỷ lệ 22,8\% và bê cái chiếm tỷ lệ cao nhất là 28,2\%. Luợng đạm thô (CP) tiêu thu của nhóm B là đáp úng nhu cầu, trong khi của nhóm A là chưa đủ (- 0,33 kg/ngày). Nhóm bò A có năng suất sũa trung bình là 16,54 kg/ngày, nhóm bò $B$ là 11,13 $\mathrm{kg} /$ ngày và trung bình cả trại là $14,15 \mathrm{~kg} / \mathrm{ngày}$. Năng suất sũa trung bình đạt cao nhất là 20,40 kg/ngày ở tháng thứ 2 và thấp nhất là $10,25 \mathrm{~kg} /$ ngày ở tháng thư 9. Nhóm $B$ có hàm lương chất béo, đạm và chất rắn tổng số lần lượt là 4,02, 3,51 và 12,66\%, cao hơn các thành phần này ở nhóm A lần lươt là 3,39, 3,09 và 11,70\%. Kết luận, tỷ lệ bò đang cho sũa của trại là tuơng đối thấp, tuy nhiên nhóm bê cái và bò cái hạu bị thì chiếm tỷ lẹ cao trong tổng đàn. Năng suất sũa của đàn bò là khá cao so với các trại chăn nuôi trong khu vưc. Chất lương sũa của nhóm B là rất tốt, nhưng của nhóm A thì tương đối thấp. 


\section{1. ĐẶT VẤN ĐỀ}

Hiện nay, con người đang sử dụng rất nhiều sản phẩm từ chăn nuôi, ngoài các sản phẩm như thịt, trứng thì sữa bò và các sản phẩm từ sữa là nguồn cung cấp dinh dưỡng rất cao cho bữa ăn hằng ngày. Theo Hồ Cao Việt và ctv. (2014), trong hơn hai thập niên vừa qua, ngành chăn nuôi bò sữa và công nghiệp sữa ở Việt Nam đã có những bước tiến quan trọng. Tuy nhiên, so với các quốc gia có nền công nghiệp sữa tiên tiến trên thế giới như Hà Lan, Úc, New Zealand, Pháp, Nhật Bản, ngành công nghiệp sữa và chăn nuôi bò sữa ở Việt Nam còn khá non trẻ và đang đứng trước những thử thách rất lớn trong tiến trình hội nhập và toàn cầu hóa. Để đạt được năng suất sữa cao, sản phẩm sữa có chất lượng và hiệu quả kinh tế tốt thì các nhà chăn nuôi phải duy trì cơ cấu đàn hợp lý, khẩu phần ăn đầy đủ dưỡng chất thiết yếu, và áp dụng các biện pháp kỹ thuật tiên tiến.

Tại Đồng bằng sông Cửu Long (ĐBSCL) nói chung, thành phố Cần Thơ nói riêng, trong những năm gần đây chăn nuôi bò sữa đã có những bước phát triển mạnh mẽ, tiêu biểu là hình thức chăn nuôi hợp tác xã và trại chăn nuôi tập trung (Lê Văn Phong và Nguyễn Văn Thu, 2016). Việc nắm được tình hình chăn nuôi, năng suất, thành phần và chất lượng sữa sẽ giúp hiểu rõ hơn về thực tế chăn nuôi tại các trang trại, qua đó đưa ra các giải pháp chăn nuôi phù hợp để phát triển bò sữa tại địa phương. Chính vì vậy, nghiên cứu được thực hiện nhằm mục tiêu chính là đánh giá hiện trạng cơ cấu đàn, năng suất và chất lượng sữa của đàn bò tại trang trại Farm Milk Cần Thơ. Bên cạnh đó, lượng thức ăn, dưỡng chất tiêu thụ và chênh lệch giữa chi phí thức ăn và tiền bán sữa cũng được ghi nhận trong trong đề tài.

\section{VÂTT LIÊU VÀ PHƯƠNG PHÁP NGHIẾN CÚU}

\subsection{Thời gian và địa điểm}

Nghiên cứu được thực hiện từ tháng 6/20195/2020 tại trang trại bò sữa Farm Milk thuộc ấp 1, xã Thới Hưng, huyện Cờ Đỏ, thành phố Cần Thơ và Phòng thí nghiệm Kỹ thuật chăn nuôi Gia súc nhai lại, Bộ môn Chăn nuôi, Khoa Nông nghiệp, Trường Đại học Cần Thơ.

\section{2. Đối tượng khảo sát}

Đề tài được thực hiện trên đàn bò sữa 408 con (tỷ lệ máu HF $>99 \%$ ), tuy nhiên khảo sát tập trung vào nhóm 93 con bò đang cho sữa. Trong đó, nhóm $\mathrm{A}$ là nhóm bò có năng suất sữa từ $15 \mathrm{~kg} /$ ngày trở lên và nhóm $\mathrm{B}$ là nhóm bò có năng suất sữa dưới 15 $\mathrm{kg} /$ ngày. Đây là hai nhóm bò được trang trại Farm Milk phân nhóm và có chế độ chăm sóc nuôi dưỡng riêng.

\subsection{Chỉ tiêu khảo sát và đánh giá}

Các chỉ tiêu khảo sát, đánh giá trong nghiên cứu bao gồm: cơ cấu đàn bò tại trại (bê cái, bò đực, bò hậu bị, bò mang thai và bò đang cho sữa), lượng thức ăn và dưỡng chất tiêu thụ, năng suất sữa, thành phần sữa (chất béo, đạm, đường, chất rắn không béo, chất rắn tổng số và điểm đông) và chênh lệch giữa chi phí thức ăn và tiền bán sữa.

\section{Bảng 1. Số mẫu khảo sát}

\begin{tabular}{lcccccccc}
\hline \multirow{2}{*}{ Chỉ tiêu } & \multirow{2}{*}{ Cơ cấu đàn } & \multicolumn{3}{c}{ Năng suất sữa } & \multicolumn{3}{c}{ Thành phần sữa } & \multirow{2}{*}{ Thức ăn } \\
\cline { 3 - 8 } & & Nhóm A & Nhóm B & Tổng số & Nhóm $\mathbf{A}$ & Nhóm $\mathbf{B}$ & Tổng số & \\
\hline Số mẫu & 408 & 55 & 38 & 93 & 288 & 228 & 516 & 6 \\
\hline
\end{tabular}

\subsection{Phương pháp khảo sát và thu thập số liệu}

Đề tài được thực hiện trên phiếu khảo sát được xây dựng trước và kết hợp ở lại trang trại trong tháng 2-3/2020 để thu thập, ghi nhận các số liệu, lấy các mẫu thức ăn và mẫu sữa để phân tích tại phòng thí nghiệm. Mẫu thức ăn tại trại được thu, cắt ngắn khoảng $0,5-1 \mathrm{~cm}$ (đối với mẫu thức ăn thô xơ), mang lên phòng thí nghiệm sấy ở $60^{\circ} \mathrm{C}$ trong 72 giờ và nghiền mịn để phân tích thành phần hóa học. Lượng thức ăn tiêu thụ = (thức ăn cung cấp - thức ăn thừa ở mỗi nhóm bò)/số bò đang cho sữa ở mỗi nhóm. Năng suất sữa thu thập từ số liệu được ghi nhận liên tục trong 9 tháng của trại, kết hợp với số liệu khảo sát thực tế tại trại trong tháng 2-3/2020. Mẫu sữa của đàn khảo sát được lấy 1 ngày/2 tuần và trong 3 lần liên tục của tháng 2-3/2020. Bò tại trang trại Farm Milk được vắt sữa 2 lần/ngày vào lúc $03 \mathrm{~h} 00$ và $15 \mathrm{~h} 00$. Ở mỗi thời điểm vắt sữa, $20 \mathrm{~mL}$ mẫu sữa/con sẽ được lấy, trữ lạnh và mang về phòng thí nghiệm để phân tích thành phần ngay trong ngày. Mẫu sữa lấy vào buổi sáng và chiều được trữ và phân tích riêng.

\subsection{Phân tích thành phần hóa học}

Mẫu thức ăn được phân tích vật chất khô (DM), vật chất hữu cơ $(\mathrm{OM})$, khoáng tổng số (Ash) và đạm thô (CP) theo phương pháp của AOAC (1990). Xơ trung tính (NDF) được xác định theo phương pháp của Van Soest et al. (1991). Mẫu sữa được phân tích 
chất béo, đạm, đường, chất rắn không béo, chất rắn tổng số và điểm đông bằng máy phân tích sữa tự động MilkoScan ${ }^{\mathrm{TM}}$ Mars (Foss, Đan Mạch). Trước khi phân tích thành phần, mẫu sữa sẽ được làm ấm bằng tủ ủ ISS-4075R (Jeiotech, Hàn Quốc) được cài đặt ở $40^{\circ} \mathrm{C}$.

\subsection{Xử lý số liệu}

Số liệu nghiên cứu được tổng hợp và xử lý sơ bộ trên phần mềm Microsoft Excel 2019, sau đó xử lý thống kê mô tả bao gồm trung bình và độ lệch chuẩn $(\ddot{\mathrm{X}} \pm \mathrm{SD})$.

\section{KẾT QUẢ VÀ THẢO LUẬN}

\subsection{Cơ cấu đàn và thức ăn cho bò}

Trang trại bò sữa Farm Milk có quy mô tổng đàn là 408 con với cơ cấu đàn được thể hiện cụ thể ở
Hình 1. Kết quả cho thấy nhóm bò đang cho sữa chiếm tỷ lệ $22,8 \%$, thấp hơn so với kết quả của Lục Nhật Huy (2016) là 43,65\% điều tra tại hợp tác xã bò sữa Evergrowth tỉnh Sóc Trăng. Cơ cấu đàn cho thấy nhóm bê cái chiếm tỷ lệ cao nhất $(28,2 \%)$, điều này cho thấy đàn bò cái hậu bị sẽ tăng nhiều trong thời gian sắp tới. Tuy nhiên, tỷ lệ nhóm bò đang cho sữa còn thấp, cần tăng cường tỷ lệ nhóm bò đang cho sữa để tăng sản lượng sữa của trại. Ngoài ra cần chú ý đến số lượng các nhóm bê trong đàn, giảm số lượng bê đực vì đây là nhóm ít mang lợi nhuận cho trại bò sữa. Cơ cấu đàn tại trại cho thấy rõ trại đang trong quá trình chuyển dịch và thay thế nhóm bò cái đang cho sữa nhiều lứa bằng nhóm bò cái hậu bị. Nhóm bò cái năng suất sữa thấp, số lứa đẻ nhiều, tỷ lệ đậu thai khi phối thấp, thường xuyên bị viêm vú và đau móng sẽ bị loại thải.

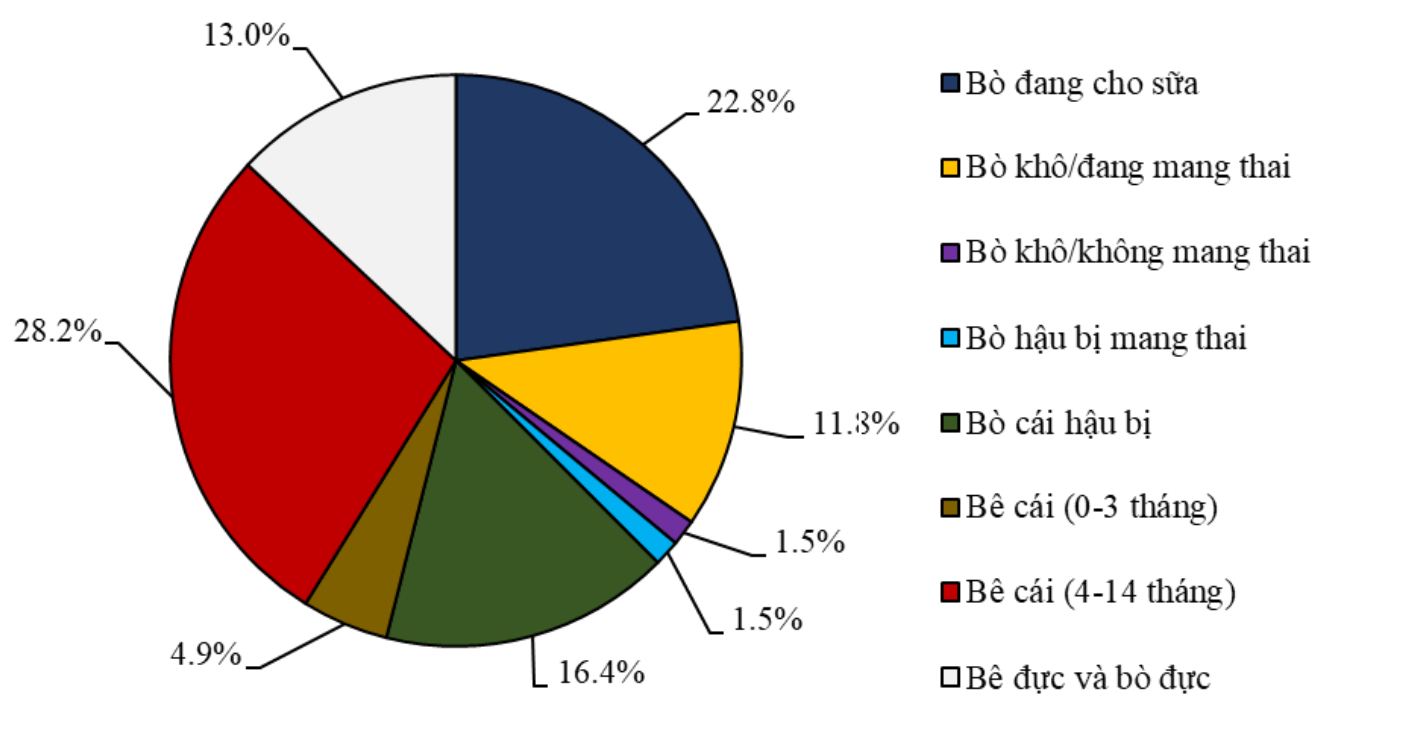

Hình 1. Cơ cấu đàn bò sữa tại Farm Milk

Một số loại thức ăn được sử dụng cho bò tại trại Farm Milk dễ tìm ở thị trường địa phương bao gồm: cỏ voi, thức ăn hỗn hợp, xơ mít ủ chua, vỏ khóm ủ chua, thân bắp ủ chua và rơm lúa (Bảng 2 ). Thức ăn hỗn hợp (TĂHH) và xơ mít ủ chua là hai loại thức ăn cung cấp CP cao nhất (15,8 và $11,41 \%)$; nhóm thức ăn còn lại như cỏ voi, vỏ khóm ủ chua, và rơm lúa cung cấp $\mathrm{CP}$ gần như tương đương nhau $(7,7,6,3$ và $6,09 \%$ ); hàm lượng $\mathrm{CP}$ thấp nhất là thân bắp ủ chua với $4,54 \%$. TĂHH có $C P 15,8 \%$ là phù hợp với kết quả của Trần Quốc Việt và ctv. (2016) mức CP nằm trong giới hạn từ $12-17 \%$ thường là mức $\mathrm{CP}$ của $\mathrm{TĂHH}$ dùng trong chăn nuôi bò sữa và bò thịt. Cỏ voi có $\mathrm{CP} 7,70 \%$ thì phù hợp với kết quả của Nguyễn Xuân Trạch và Đinh Văn Cải (2008) là 7$9 \%$. Tuy nhiên, kết quả này thấp hơn so với nghiên cứu của Nguyễn Nhựt Xuân Dung và ctv. (2007) là $8,52 \%$, điều này là do cỏ được trồng tại các vùng đất có dinh dưỡng khác nhau. Xơ mít ủ chua có CP khá cao $(11,41 \%)$, cao hơn kết quả của Hồ Thanh Thâm (2017) phân tích trên trái mít giống Thái có CP trong hạt là cao nhất $10,44 \%$, kế đến là vỏ $8,70 \%$ và sau cùng là cùi $7,02 \%$. Đối với thân cây bắp ủ chua, $\mathrm{CP}$ $4,54 \%$ phù hợp với kết quả của Nguyễn Xuân Trạch và Đinh Văn Cải (2008), CP trong cây bắp già sau khi thu hoạch trái dao động từ 4-7\%. Theo Phùng Quốc Quảng và Nguyễn Xuân Trạch (2003), trong các loại thức ăn của bò sữa, một số có hàm lượng $\mathrm{DM}$ cao, một số khác có hàm lượng DM thấp. Thức ăn tại trại Farm Milk có $\mathrm{DM}$ cao nhất là rơm lúa và TĂHH $92,52 \%$ và $92,23 \%$, nhóm thức ăn còn lại gồm: cỏ voi, xơ mít ủ chua, vỏ khóm ủ chua và thân 
bắp ủ chua có DM dao động từ 14,65-20-52\%. Với kết quả này, TĂHH và rơm lúa là hai loại thức ăn dễ bảo quản và sử dụng trong thời gian dài, có thể dự trữ để cung cấp cho bò trong giai đoạn thiếu thức ăn thô xanh. Nhóm thức ăn cỏ voi, xơ mít, vỏ khóm, thân bắp là nhóm thức ăn chứa nhiều nước với hàm lượng vật chất khô thấp nên khó bảo quản được lâu. Nhóm thức ăn có NDF cao là thân bắp ủ chua, cỏ voi và rơm lúa $(67,9,61,8$ và $58,2 \%)$, đây là những thức ăn cung cấp xơ chính cho bò. TĂHH, xơ mít ủ chua và vỏ khóm ủ chua có hàm lượng xơ thấp và gần tương đương nhau (42,2-42,6\%). Thức ăn có chất hữu cơ $(\mathrm{OM})$ cao nhất là TĂHH và xơ mít $(92,6 \%$ và $93,49 \%)$ nhưng lại có khoáng tổng số $(7,40 \%$ và $6,51 \%)$ thấp hơn so với các thức ăn còn lại $(11,63-26,44 \%)$.

Bảng 2. Thành phần hóa học của thức ăn

\begin{tabular}{lrrrrr}
\hline \multirow{2}{*}{ Thức ăn } & \multicolumn{5}{c}{ Thành phần hóa học (\%) } \\
\cline { 2 - 6 } & DM & OM & Ash & CP & NDF \\
\hline Cỏ voi & 15,25 & 88,37 & 11,63 & 7,70 & 61,8 \\
TĂHH & 92,23 & 92,60 & 7,40 & 15,80 & 42,2 \\
Xơ mít ủ chua & 20,52 & 93,49 & 6,51 & 11,41 & 42,4 \\
Vỏ khóm ủ chua & 14,65 & 73,56 & 26,44 & 6,30 & 42,6 \\
Thân bắp ủ chua & 16,08 & 83,65 & 16,35 & 4,54 & 67,9 \\
Rơm lúa & 92,52 & 83,75 & 16,25 & 6,09 & 62,4 \\
\hline
\end{tabular}

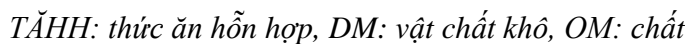
hưu co; Ash: khoáng tổng số, CP: đạm thô, NDF: $x o^{\circ}$ trung tính.
Nhìn chung, các loại thức ăn khác nhau tại trại đều cung cấp được những dưỡng chất khác nhau và mỗi loại thức ăn đều có ưu điểm riêng khi sử dụng làm thức ăn cho bò sữa. Các loại thức ăn chính này cung cấp đủ nhu cầu cho bò để duy trì và tiết sữa, cung cấp đạm thô chính là thức ăn hỗn hợp và xơ mít, cung cấp xơ chính là cỏ voi, thân bắp ủ chua và rơm lúa, cung cấp khoáng chính là vỏ khóm ủ chua. Khi phối trộn các thức ăn lại với nhau sẽ cho ra một khẩu phần cân đối cho bò. Tuy nhiên, một số vấn đề trại đang gặp phải là thiếu hụt thức ăn vào mùa mưa và nguồn cung cấp một số thức ăn phụ phẩm từ sản xuất như xơ mít và vỏ khóm chưa ổn định về số lượng, do đó trại phải thường xuyên thay đổi khẩu phần ăn trong tháng, điều này không tốt cho bò đặt biệt là nhóm bò đang cho sữa.

\subsection{Thức ăn tiêu thụ}

Theo Nguyễn Xuân Trạch và Mai Thị Thơm (2004), nguyên tắc chung khi tính nhu cầu cho bò vắt sữa là cung cấp đầy đủ các dinh dưỡng cần cho sự duy trì cơ thể, sản xuất sữa; ngoài ra còn phải cung cấp nhu cầu mang thai và tăng trọng. Khi xác định tiêu chuẩn ăn cho bò vắt sữa cần phải xem xét thêm về đặc điểm giống, tuổi, mức độ dinh dưỡng, lứa đẻ, thời gian cho sữa, thể trạng của bò. Lượng thức ăn và dưỡng chất tiêu thụ của bò đang cho sữa tại trại Farm Milk được thể hiện qua Bảng 3.

\section{Bảng 3. Lượng thức ăn và dưỡng chất tiêu thụ}

\begin{tabular}{|c|c|c|c|c|c|c|}
\hline \multirow{2}{*}{ Thức ăn } & \multicolumn{3}{|c|}{ Nhóm A ( $\geq 15$ kg sữa/ngày) } & \multicolumn{3}{|c|}{ Nhóm B (<15 kg sữa/ngày) } \\
\hline & Tươi & DM & $\mathbf{C P}$ & Tưoi & DM & $\mathbf{C P}$ \\
\hline \multicolumn{7}{|l|}{ Lượng ăn, kg/ngày } \\
\hline Cỏ voi & 12,95 & 1,98 & 0,15 & 15,13 & 2,31 & 0,18 \\
\hline Thức ăn hỗn hợp & 11,35 & 10,47 & 1,65 & 9,70 & 8,95 & 1,41 \\
\hline Xơ mít ủ chua & 8,65 & 1,78 & 0,20 & 8,56 & 1,76 & 0,20 \\
\hline Vỏ khóm ủ chua & 8,65 & 1,27 & 0,08 & 8,65 & 1,27 & 0,08 \\
\hline Thân bắp ủ chua & 4,33 & 0,70 & 0,03 & 2,15 & 0,35 & 0,02 \\
\hline Rơm lúa & 2,70 & 2,50 & 0,15 & 2,15 & 1,99 & 0,12 \\
\hline Tổng số & 48,63 & 18,68 & 2,27 & 46,34 & 16,61 & 2,01 \\
\hline \% Thức ăn thô & - & 43,96 & - & - & 46,15 & . \\
\hline \% Thức ăn hỗn hợp & - & 56,04 & - & - & 53,85 & \\
\hline
\end{tabular}

DM: vật chất khô, CP: đạm thô.

Lượng ăn (kg/ngày) giữa hai nhóm bò không chênh lệch quá nhiều, nhóm $\mathrm{A}$ có lượng $\mathrm{DM}$ và $\mathrm{CP}$ tiêu thụ lần lượt là 18,68 và $2,27 \mathrm{~kg} / \mathrm{ngày}$, với nhóm $\mathrm{B}$ là 16,61 và $2,01 \mathrm{~kg} / \mathrm{ngày}$. Tỷ lệ thức ăn thô và thức ăn hỗn hợp trong khẩu phần của hai nhóm bò có sự khác nhau không đáng kể. Phần trăm $\mathrm{CP}$ khẩu phần của nhóm $\mathrm{A}$ là $12,16 \%$ và của nhóm $\mathrm{B}$ là $12,09 \%$ và sự khác biệt ở hai nhóm bò rất ít. Theo Nguyễn Xuân Trạch và Đinh Văn Cải (2008), nhu cầu $\mathrm{CP}$ theo nhóm bò có tỷ lệ mỡ sữa khác nhau là khác nhau. Xác định tiêu chuẩn ăn cho bò là công việc khó khăn và phức tạp. Cách đơn giản nhất là dựa vào bảng có sẵn, như tiêu chuẩn của NRC (2001). Khẩu phần ăn đối với nhóm $\mathrm{B}$ (mỡ sữa 4,02\%, năng suất sữa 11,13 $\mathrm{kg} / \mathrm{con} / \mathrm{ngày}$ ) có phần trăm $\mathrm{CP}$ từ $11,9-12,6 \%$, đối với nhóm $\mathrm{A}$ (mỡ sữa $3,39 \%$, năng suất sữa 16,54 $\mathrm{kg} / \mathrm{con} /$ ngày) có phần trăm $\mathrm{CP}$ từ $16,6-18 \%$. Như vậy, lượng $\mathrm{CP}$ tiêu thụ tối thiểu đối với nhóm $\mathrm{B}$ là 
$1,98 \mathrm{~kg} /$ ngày và nhóm $\mathrm{A}$ là $3,10 \mathrm{~kg} / \mathrm{ngày}$. So với giá trị lượng $\mathrm{CP}$ ăn vào ở Bảng 3 thì lượng $\mathrm{CP}$ tiêu thụ thực tế của nhóm $B$ là vừa đủ nhu cầu của gia súc và của nhóm $\mathrm{A}$ là chưa đủ (thiếu $0,83 \mathrm{~kg} /$ ngày). Điều này có thể do hàm lượng $\mathrm{CP}$ trong TĂHH thấp, dẫn đến việc $\mathrm{CP}$ khẩu phần đối với nhóm $\mathrm{A}$ bị thiếu, do đó cần sử dụng $\mathrm{TA} H \mathrm{H} H$ có hàm lượng $\mathrm{CP}$ cao hơn để đáp ứng nhu cầu sản xuất của bò ở nhóm $\mathrm{A}$ nhằm giúp bò cho sữa được tốt hơn cũng như duy trì được thể trạng khỏe mạnh.

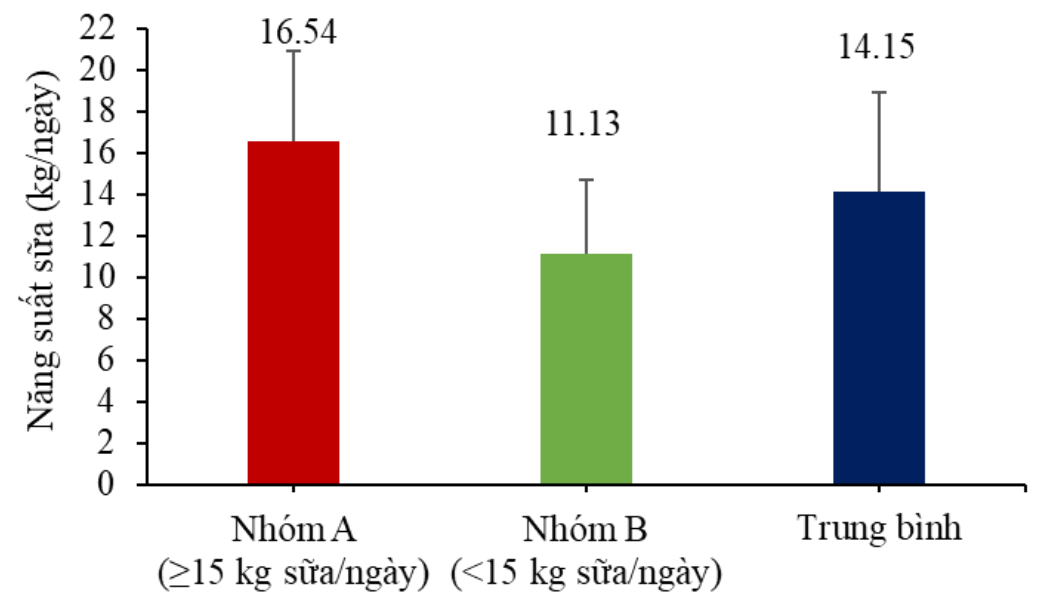

\section{Hình 2. Năng suất sữa trung bình}

Hình 2 cho thấy sự chênh lệch về năng suất sữa trung bình là khá lớn giữa hai nhóm $\mathrm{A}$ và $\mathrm{B}$. Nhóm A có năng suất cao hơn nhóm $B$ là $5,41 \mathrm{~kg} / \mathrm{con} /$ ngày và cao hơn năng suất trung bình của hai nhóm 2,39 $\mathrm{kg} / \mathrm{con} /$ ngày $(16,9 \%)$. Qua đó cho thấy năng suất sữa của nhóm $\mathrm{A}$ là rất cao, chiếm chủ yếu trong tổng sản lượng sữa của đàn bò tại trại. Bò năng suất sữa cao cần được chăm sóc kỹ hơn để duy trì được năng suất, đối với nhóm A tại trại được chăm sóc chu đáo hơn về điều kiện chuồng trại, khẩu phần ăn cũng như

\subsection{Năng suất và thành phần sữa}

Năng suất sữa cao nhất là $28,10 \mathrm{~kg} / \mathrm{con} /$ ngày và thấp nhất là $4,40 \mathrm{~kg} / \mathrm{con} /$ ngày. Năng suất sữa bình quân của trại là $14,15 \mathrm{~kg} / \mathrm{con} / \mathrm{ngày}$, cao hơn so với kết quả của Lục Nhật Huy (2016) là 11,28 $\mathrm{kg} / \mathrm{con} /$ ngày khi điều tra tại hợp tác xã bò sữa Evergrowth tỉnh Sóc Trăng. Nhìn chung năng suất sữa của trại Farm Milk là khá cao so với điều kiện chăn nuôi tại khu vực phía Nam.

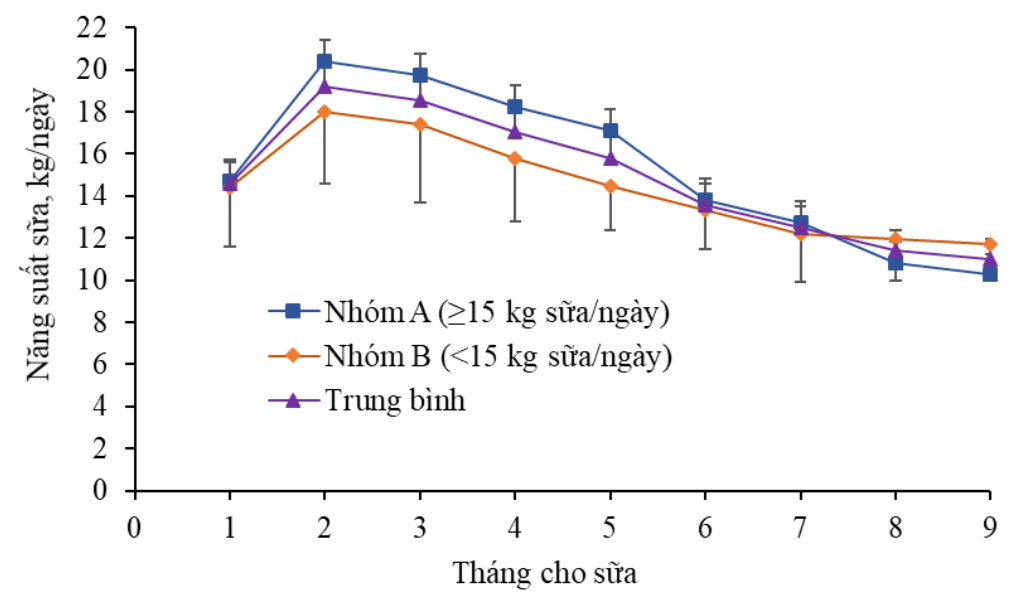

Hình 3. Năng suất sữa theo tháng cho sữa 
Theo Nguyễn Văn Tuế và ctv. (2010), năng suất sữa theo tháng của chu kỳ cho sữa cũng là một chỉ tiêu phản ánh sức sản suất của bò sữa. Trong một chu kỳ sữa ở bò được chia làm 2 giai đoạn: giai đoạn 1 bắt đầu từ khi đẻ, năng suất sữa có xu hướng tăng từ từ, đạt giá trị cao ở 60 ngày đến 90 ngày; giai đoạn 2 , năng suất sữa có xu hướng giảm thấp song song với quá trình thoái hóa của tuyến bào. Tại Farm Milk, năng suất sữa của trại theo tháng cho sữa cao nhất $20,40 \mathrm{~kg} / \mathrm{con} /$ ngày và thấp nhất là 10,25 $\mathrm{kg} /$ con/ngày (Hình 3).

Hình 3 cho thấy năng suất sữa của hai nhóm bò tăng rất nhanh và đạt đỉnh điểm vào tháng thứ 2 cho sữa và giảm dần đến tháng thứ 9 . Kết quả này phù hợp với kết quả của Nguyễn Văn Tuế và ctv. (2010). Cho thấy khả năng tiết sữa của các nhóm bò khá ổn định, đàn bò thích nghi với môi trường sống. Nguyễn Văn Thưởng (1995) cho thấy năng suất sữa bò đạt cao nhất ở tháng thứ hai hoặc thứ 3 sau đó giảm dần, mức độ giảm từ từ hay giảm nhanh còn phụ thuộc vào giống, đặc điểm cá thể và chăm sóc nuôi dưỡng. Ở những bò có sản lượng sữa cao đường cong tiết sữa giảm từ từ và đều hơn. Nguyễn

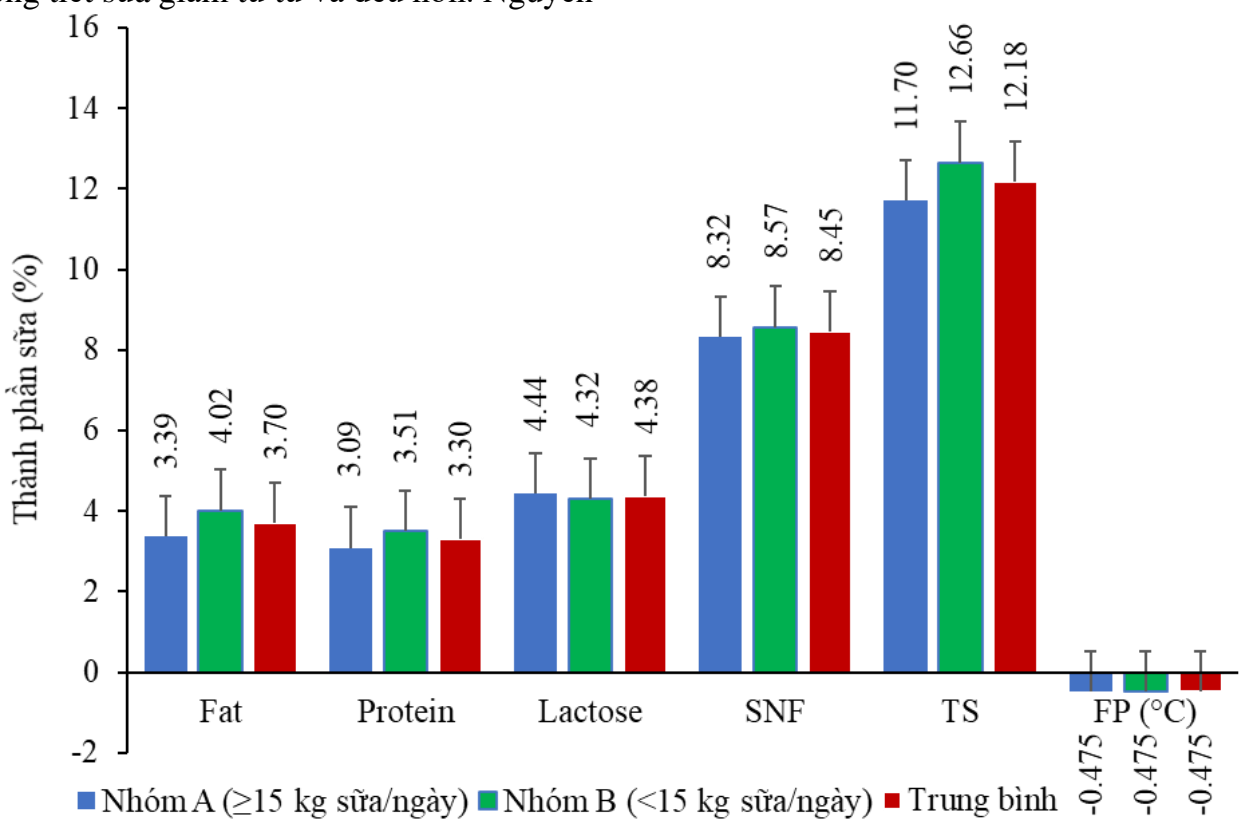

\section{Hình 4. Thành phần sữa}

Thành phần sữa tại trại Farm Milk được thể hiện qua Hình 4 . Thành phần sữa của hai nhóm bò có sự chênh lệch rất lớn. Sữa của nhóm $\mathrm{B}$ có hàm lượng chất béo (fat) cao hơn nhóm A là 18,58\%. Đạm (protein) của nhóm $\mathrm{B}$ cao hơn nhóm $\mathrm{A}$ là $13,59 \%$. Chất rắn không béo (SNF) và chất rắn tổng số $(\mathrm{TS})$ của nhóm $B$ cao hơn nhóm $A$ lần lượt là 3 và $8,2 \%$. Đường (lactose) và điểm đông $(\mathrm{FP})$ của sữa ở 2
Quốc Đạt (1999) cho biết năng suất sữa của bò lai $1 / 2 \mathrm{HF}$; $3 / 4 \mathrm{HF}$ và $7 / 8 \mathrm{HF}$ nuôi tại thành phố Hồ Chí Minh đạt đỉnh điểm ở tháng thứ hai của chu kỳ tiết sữa. Trần Quang Hạnh và Đặng Vũ Bình (2007) cũng nhận thấy năng suất sữa bò HF đạt cao nhất ở tháng sữa thứ hai của chu kỳ tiết sữa, sau đó giảm dần dần. Qua Hình 3 cũng cho thấy, năng suất sữa của cả hai nhóm đều giảm rất chậm và duy trì mức cho sữa khá cao đến tháng cho sữa thứ 9 , nhóm $\mathrm{A}$ là $10,25 \mathrm{~kg} / \mathrm{con} / \mathrm{ngày}$, nhóm $\mathrm{B}$ là $11,72 \mathrm{~kg} / \mathrm{con} /$ ngày và trung bình hai nhóm là $10,98 \mathrm{~kg} / \mathrm{con} /$ ngày. Năng suất sữa của nhóm $\mathrm{B}$ cao hơn $14,34 \%$ so với nhóm A ở tháng thứ 9 của chu kỳ tiết sữa. Nhìn chung, năng suất sữa của trại là khá tốt trong chu kì 9 tháng cho sữa, tuy nhiên số lần phối đậu thai là còn khá cao, đối với nhóm $\mathrm{A}$ là 2,33 lần/con và nhóm $\mathrm{B}$ là 3,11 lần/con. Kết quả này cao hơn nghiên cứu của Lê Văn Phong và Nguyễn Văn Thu (2016) với số lần phối đậu thai của bò lai $\mathrm{F} 1$ là 2,0 lần/con; $\mathrm{F} 2$ là 2,4 lần/con; F3 là 2,8 lần/con. Điều này sẽ gây ảnh hưởng đến việc kéo dài thời gian cho sữa của bò, trong khi năng suất sữa giảm dần theo tháng cho sữa nên không mang lại hiệu quả kinh tế cho trại. 
thì nhóm $\mathrm{A}$ lại có chất lượng sữa thấp hơn nhóm $\mathrm{B}$, điều này cho thấy trại cần cân đối kỹ hơn ở vấn đề dinh dưỡng cho nhóm $\mathrm{A}$ để đảm bảo được chất lượng sữa tốt hơn.

\subsection{Chênh lệch chi phí thức ăn và tiền bán sữa}

Trong chăn nuôi, lợi nhuận là yếu tố quan trọng nhất, người chăn nuôi bò sữa cũng như chăn nuôi động vật khác luôn chú trọng đến hai vấn đề là giá thành bán sản phẩm chăn nuôi và chi phí thức ăn cho chăn nuôi. Giá thành thu mua sữa được quyết định dựa trên chất lượng dinh dưỡng của sữa, trong đó mỡ sữa thường là tiêu chí để so sánh đánh giá và phân loại sữa. Theo tiêu chuẩn của Vinamilk thì giá thua mua sữa hiện nay đối với sữa loại 1 (mỡ sữa $>3,4 \%$ ) là $14.000 \mathrm{VND} / \mathrm{kg}$ và sữa loại 2 (mỡ sữa $<3,4 \%$ ) là $12.500 \mathrm{VND} / \mathrm{kg}$. So với thành phần mỡ sữa tại trại Farm Milk thì sữa của nhóm $\mathrm{A}$ là sữa loại 2 và nhóm $B$ là sữa loại 1 .

Bảng 4. Chênh lệch giữa chi phí thức ăn và tiền bán sữa

\begin{tabular}{|c|c|c|}
\hline \multirow[b]{2}{*}{ Chỉ tiêu } & \multicolumn{2}{|c|}{ Nhóm bò } \\
\hline & $\begin{array}{r}\text { Nhóm A } \\
\text { ( } \geq 15 \text { kg } \\
\text { sữa/ngày) } \\
\end{array}$ & $\begin{array}{r}\text { Nhóm B } \\
\text { (<15 kg } \\
\text { sữa/ngày) }\end{array}$ \\
\hline $\begin{array}{l}\text { Chi phí thức ăn, } \\
\text { VNĐ/con/ngày }\end{array}$ & & \\
\hline Cỏ voi & 5.570 & 6.500 \\
\hline Thức ăn hỗn hợp & 78.540 & 67.120 \\
\hline Xơ mít ủ chua & 8.650 & 8.560 \\
\hline Vỏ khóm ủ chua & 3.890 & 3.890 \\
\hline Thân bắp ủ chua & 2.810 & 1.400 \\
\hline Rơm lúa & 2.700 & 2.150 \\
\hline Tổng chi phi thức ăn & 102.160 & 89.620 \\
\hline $\begin{array}{l}\text { Tiền bán sữa, } \\
\text { VNĐ/con/ngày }\end{array}$ & 206.750 & 155.820 \\
\hline $\begin{array}{l}\text { Chênh lệch, } \\
\text { VNĐ/con/ngày }\end{array}$ & 104.590 & 66.200 \\
\hline
\end{tabular}

Giá thức ăn bao gồm: cỏ voi (430 đ/kg), thức ăn hỗn hợp $(6.920 \mathrm{~d} / \mathrm{kg})$, xơ mít ủ chua $(1.000 \mathrm{~d} / \mathrm{kg})$, vỏ khóm ủ chua $(450 \mathrm{~d} / \mathrm{kg})$, thân bắp ủ chua $(650$ đ $/ \mathrm{kg})$, rơm lúa $(1.000 \mathrm{~d} / \mathrm{kg})$. Giá bán sữa của nhóm A là $12.500 \mathrm{~d} / \mathrm{kg}$ và của nhóm $\mathrm{B}$ là $14.000 \mathrm{~d} / \mathrm{kg}$.

Bảng 4 cho thấy chênh lệch giữa chi phí thức ăn và tiền bán sữa của nhóm $\mathrm{A}$ là cao hơn so với nhóm $B$ là $38.390 \mathrm{VND} /$ con/ngày. Tuy giá thành thu mua sữa đối với nhóm $\mathrm{A}$ là thấp hơn nhưng nhóm bò này lại có năng suất cao hơn nhóm $\mathrm{B}$ là 4,41 $\mathrm{kg} / \mathrm{con} / \mathrm{ngày}$, do đó về hiệu quả kinh tế thì nhóm $\mathrm{A}$ có hiệu quả kinh tế cao hơn.

\section{KẾT LUẬN VÀ ĐỀ XUẤT}

\subsection{Kết luận}

Nhìn chung, tình hình chăn nuôi tại trại Farm Milk đang là khá tốt. Tỷ lệ bò đang cho sữa của trại là tương đối thấp, tuy nhiên cơ cấu đàn đang chuyển dịch theo hướng tích cực với nhiều bò cái hậu bị. Thức ăn tại trại có chất lượng khá tốt nhưng nguồn cung cấp chưa được dồi dào. Khẩu phần ăn có hàm lượng $\mathrm{CP}$ tương đối đủ cho nhóm $\mathrm{B}$ và hơi thấp với nhóm A. Năng suất sữa là khá cao so với các trại chăn nuôi nhỏ lẻ hay hợp tác xã, biểu đồ năng suất sữa theo tháng cho sữa lên nhanh nhưng giảm chậm điều này có lợi cho trại chăn nuôi. Chất lượng sữa của nhóm $\mathrm{B}$ là rất tốt, nhưng của nhóm $\mathrm{A}$ thì tương đối thấp. Chênh lệch giữa chi phí thức ăn và tiền bán sữa của nhóm $\mathrm{A}$ là cao hơn so với nhóm $\mathrm{B}$.

\section{2. Đề xuất}

Đẩy mạnh việc loại thải các bò nhiều lứa và cải tiến kỹ thuật cho việc phối giống khó đậu thai, tăng cường nhiều bò cái hậu bị để thay thế cho nhóm bò có năng suất kém. Cân đối lại khẩu phần ăn cho phù hợp nhu cầu với nhóm bò $\mathrm{A}$. Cần chú trọng cải tiến dinh dưỡng và kỹ thuật nuôi để nâng cao chất lượng sữa của nhóm bò $\mathrm{A}$.

\section{TÀI LIẸU THAM KHẢO}

AOAC (1990). Offical methods of analysis (15 $5^{\text {th }}$ ed.). Association of Official Analytical Chemists.

Hồ Cao Việt, Kazuyoshi Taya, Kenji Togashi, Moriyama Hiromitsu, Vũ Chí Cương, Chu Anh Dũng và Tăng Xuân Lưu (2014). Phát triển ngành công nghiệp sũua và chăn nuôi bò sũa ở Việt Nam. 287 trang.

Hồ Thanh Thâm (2017). Đánh giá chất lượng phụ phẩm từ quá trình chế biến trái mít. Tạp chí Nông Nghiệp và Phát triển Nông thôn, 2017(8), 89-93.

Lê Văn Phong và Nguyễn Văn Thu (2016). Điều tra về sinh trưởng, sản xuất và kĩ thuật nuôi bò sữa tại nông trường sông Hậu, hợp tác xã bò sữa Long Hòa và Evergrowth ở đồng bằng sông Cửu Long. Tạp chí Khoa học truòng Đại học Cần Tho; 2016(2), 48-55.

Lục Nhật Huy, Nguyễn Văn Hớn và Nguyễn Trọng Ngữ (2016). Khảo sát tình hình chăn nuôi bò sữa và nguồn thức ăn cho gia súc tại hợp tác xã Evergrowth, Sóc Trăng. Tạp chi Khoa họ Kỹ thuật Chăn nuôi, 205, 71-77.

Nguyễn Nhựt Xuân Dung, Lưu Hữu Mãnh và Nguyễn Thị Mộng Nhi (2007). Thành phần hóa học và giá trị dịnh dưỡng của một số giống cây thức ăn gia súc họ hòa thảo và họ đậu trồng tại thành phố Cần Thơ. Tạp chí Khoa học trương Đại học Cần Tho', 7, 183-192 
Nguyễn Quốc Đạt (1999). Một số đặc điểm về giống của bò cái lai (Holstein Friesian $\times$ lai Sindhi) huớng sũ̃a nuôi tại Thành phố Hồ Chí Minh (Luận án tiến sĩ nông nghiệp). Viện Khoa học Kỹ thuật Nông nghiệp.

Nguyễn Văn Thưởng (1995). Kỹ thuật nuôi bò sũa bò thịt ở gia đình. NXB Nông nghiệp.

Nguyễn Văn Tuế, Đặng Vũ Bình và Mai Văn Sánh, 2010. Năng suất sữa bò lai $F 1, F 2$ và $F 3$ (Holstein $\times$ lai Sind) nuôi trong nông hộ tỉnh Bắc Ninh. Tạp chi Khoa học Kỹ thuật Chăn nuôi, 26, 9-16.

Nguyễn Xuân Trạch và Đinh Văn Cải (2008). Dinh dương và thức ăn trong chăn nuôi bò sũa. Dự án bò sữa Việt-Bỉ.

Nguyễn Xuân Trạch và Mai Thị Thơm (2004). Giáo trình Chăn nuôi trâu bò. NXB Nông nghiệp.

NRC (2001). Nutrient requirements of dairy cattle ( $7^{\text {th }}$ ed.). National Academy Press.
Phùng Quốc Quảng và Nguyễn Xuân Trạch (2003). Thức ăn và dinh dữ̛ng bò sũa. NXB Nông nghiệp.

Trần Quang Hạnh và Đặng Vũ Bình (2007). Một số chỉ tiêu năng suất và chất lượng sữa của bò Holstein Friessian nuôi tại tỉnh Lâm Đồng. Tạp chi KHKT Nông nghiệp truò̀ng Đại học Nông nghiệp Hà Nội, 2007(3), 45-47.

Trần Quốc Việt, Trần Thị Bích Ngọc, Nguyễn Quốc Đạt, Nguyễn Thanh Bình, Ngô Thành Vinh, Nguyễn Hữu Tào, Nguyễn Văn Thiện và Trần Kim Ngọc (2006). Đánh giá giá trị dinh duõng và hiệu quả nuôi duỡng của thức ăn thô dạng viên trong chăn nuôi bò sũa . Báo cáo Khoa học Viện chăn nuôi.

Van Soest, P. J., Robertson, J. B., \& Lewis, B. A. (1991). Methods for dietary fiber, neutral detergent fiber and non-starch polysaccharides in relation to animal productinon. Journal of Dairy Science, 74, 3583-3597. 